\title{
THÔNG BÁO TRƯờnG HợP PHẪU THUẠTT LẤY HUYẾT KHỐI ĐộNG MẠCH PHỔI CẤP TÍNH TRÊN BỆNH NHÂN ĐA CHẤN THƯƠNG TẠI BỆNH VIỆN VIẸTT ĐỨC
}

Nguyễn Hũu Ước*, Phùng Duy Hồng Son*

\section{TÓM TẮT}

Thuyên tắc động mạch phổi là bệnh lý phổi gây tử vong cao nhất và là nguyên nhân đứng thứ ba gây tử vong ở bệnh viện. Tỉ lệ tử vong có thể tới $65 \%$ nếu chẩn đoán muộn ở giai đoạn có trụy tim mạch. Đã có một số báo cáo trong nước về điều trị nội - ngoại khoa thuyên tắc động mạch phổi trong môi trường ngoại khoa, song chưa có báo cáo nào về điều trị thuyên tắc động mạch phổi trên bệnh nhân đa chấn thương. Chúng tôi thông báo một trường hợp bệnh nhân nữ 65 tuổi, bị TTĐMP cấp trên bệnh nhân đa chấn thương đã được phẫu thuật thành công tại khoa Tim mạch và lồng ngực, bệnh viện Hữu nghị Việt Đức, vào tháng 09/2016, nhằm rút ra nhận xét ban đầu về loại thương tổn nguy hiểm này và nhìn lại y văn.

SUMMARY: Pulmonary embolism (PE) is the most lethal pulmonary disorder, with high mortality if late diagnosis in severe type (65\%) with cardiac shock. There ware some national reseaches about this complication, but not yet report about acute PE in multi-trauma patient. We report a case of 65- year-old woman with multi-trauma, who underwent success emergency surgical embolectomy from bilateral pulmonary arteries in department of cardiovascular and thoracic surgery, Viet Duc university hospital and analysis literatures.
Từ khóa: Thuyên tắc động mạch phổi, huyết khối tĩnh mach sâu chi duoói, lấy huyết khối, PE, pulmonary embolectomy.

\section{I. ĐẶT VẤN ĐỀ}

Thuyên tắc động mạch phổi (TTĐMP) là bệnh lý phổi gây tử vong cao nhất và là nguyên nhân đứng thứ ba gây tử vong ở bệnh viện $[1,2]$. Tỉ lệ tử vong tại bệnh viện đối với bệnh nhân TTĐMP có huyết động ổn định là $8,1 \%$, ở bệnh nhân có trụy tim mạch là $25 \%$ và ở bệnh nhân phải ép tim là $65 \%$ [3]. TTĐMP cấp tính trong môi trường ngoại khoa chủ yếu do di chuyển huyết khối từ tĩnh mạch sâu chi dưới $[1,4]$. Do các triệu chứng và biểu hiện bệnh không điển hình nên rất khó chẩn đoán và thường bị nhầm với các bệnh lý phổi khác hoặc bỏ sót. Chúng tôi thông báo một trường TTĐMP trên bệnh nhân đa chấn thương đã được phẫu thuật cấp cứu thành công tại khoa tim mạch lồng ngực bệnh viện Hữu nghị Việt Đức 09/2016.

\section{II. ĐỐI TƯợNG VÀ PHƯƠNG PHÁP NGHIÊN CÚU.}

Mô tả trường hợp lâm sàng hiếm gặp về đặc điểm lâm sàng, cận lâm sàng, xử trí, kết quả và nhìn lại y văn.

* Khoa Phẫu thuật tim mach lồng ngưc, Bệnh viện Hũu nghị Việt Đức Nguoòi chịu trách nhiệm khoa học: PGS.TS. Nguyễn Hũu Uớc Ngày nhận bài: 01/04/2018 - Ngày Cho Phép Đăng: 10/04/2018 Phản Biện Khoa học: GS.TS. Bùi Đức Phú PGS.TS. Đặng Ngọc Hùng 


\section{KẾT QUẢ NGHIÊN CỨU.}

Bệnh nhân nữ 65 tuổi, chưa có tiền sử bệnh lý, bị tai nạn giao thông đi bộ va chạm xe máy, với chẩn đoán khi nhập viện: chấn thương gan, gãy hở hai xương cẳng chân phải (Hình 1).

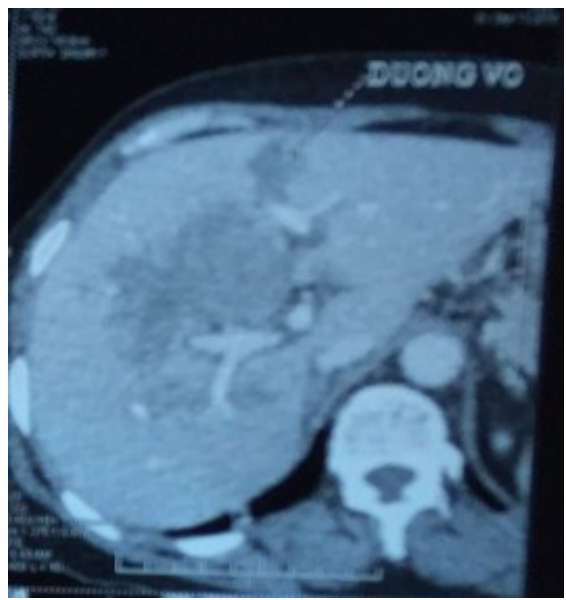

A

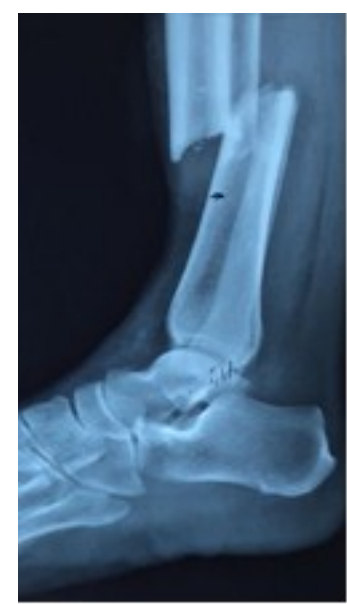

$\mathrm{B}$

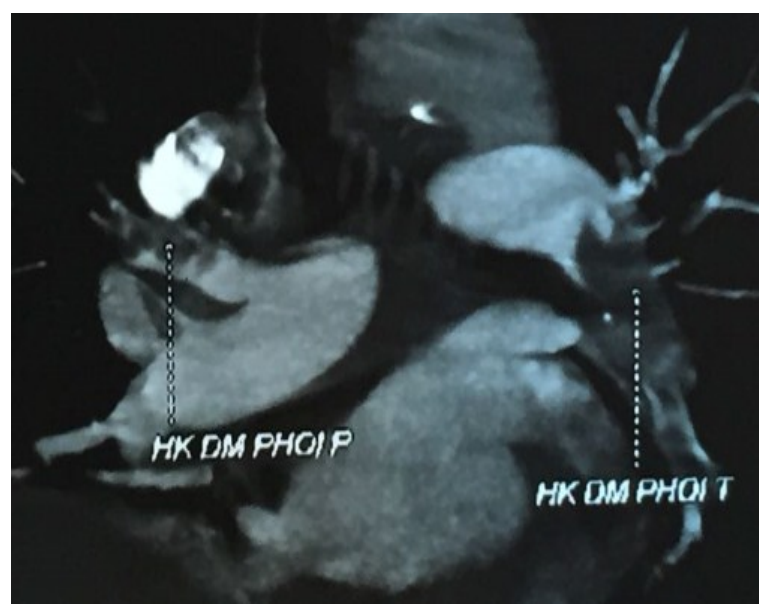

$\mathrm{C}$

Hinh 1: $\boldsymbol{A}$ - Hình ảnh chup cắt lớp vi tính chấn thuơng gan; $\boldsymbol{B}$ - X-quang hình ảnh gãy xuơng cẳng chân; $\boldsymbol{C}$ - Hình ảnh chụp cắt lớp vi tính động mạch phổi.

Do chấn thương gan là nặng nhất, nên bệnh nhân được cho vào khoa Cấp cứu tiêu hóa theo dõi sau khi sơ cứu và làm chẩn đoán, không dùng thuốc chống đông dự phòng. Ngày thứ hai sau nhập viện xuất hiện khó thở tăng, đau ngực, hội chẩn chuyên khoa tim mạch chỉ định chụp cắt lớp vi tính đa dãy (MSCT) ngực có cản quang. Trên phim MSCT (hình 1C), có hình ảnh huyết khối động mạch phổi chiếm gần hoàn toàn động mạch phổi trái, bán phần động mạch phổi phải lan sang nhánh thùy đỉnh và phân thùy sau, dịch khoang màng phổi hai bên, xẹp thụ động nhu mô phổi hai bên. Bệnh nhân được chuyển đến phòng hồi sức tích cực, thở không xâm nhập ngắt quãng, nhưng huyết động dao động nhiều, mạch nhanh, phải dùng thuốc trợ tim dobutamin. Siêu âm Doppler mạch máu cấp cứu tại giường thấy huyết khối tĩnh mạch sâu chi dưới bên phải, nhu mô gan có ổ đụng giập, tụ máu kích thước $81 \times 90 \mathrm{~mm}$; xét nghiệm D-dimer tăng cao 36940. Hội chẩn đa chuyên khoa thống nhất bước đầu điều trị bảo tồn, song do bệnh nhân có chấn thương gan nên không thể dùng thuốc tiêu sợi huyết hay thuốc chống đông. Sau 3 giờ, tình trạng bệnh nhân chuyển biến xấu, với nhịp thở nhanh, $\mathrm{SpO}_{2}$ giảm, mạch nhanh, huyết áp động mạch tụt. Bệnh nhân được đặt nội khí quản cấp cứu và thở máy. Hội chẩn lại đa chuyên khoa và quyết định phẫu thuật tim hở cấp cứu lấy huyết khối động mạch phổi - một phương pháp điều trị đã có kinh nghiệm tại bệnh viện Việt Đức.

Bệnh nhân chuyển sang phòng mổ tim mạch để mổ cấp cứu với tuần hoàn ngoài cơ thể. Qui trình mổ: Mở đường giữa xương ức; Heparin cho liều $200 \mathrm{UI} / \mathrm{kg}$ và thử $\mathrm{ACT}$ duy trì đạt 300-400 c; Lắp tuần hoàn ngoài cơ thể qua canuyn động mạch chủ, tĩnh mạch chủ trên và dưới; Chạy tuần hoàn ngoài cơ thể toàn bộ, thắt tĩnh mạch chủ trên và dưới; Mở động mạch phổi ngay sát ngã ba, kéo dài sang động mạch phổi trái; Dùng dụng cụ Mirizy [1] lấy ra 
nhiều huyết khối hình cây động mạch phổi trái (hình 2B); Mở động mạch phổi phải sát tĩnh mạch chủ trên, lấy ra nhiều huyết khối; Bơm rửa làm sạch động mạch phổi hai bên bằng dung dịch nước muối sinh lý ấm; Mở nhĩ phải kiểm tra không có huyết khối; Đóng nhĩ phải, đuổi khí, đóng các đường mở động mạch phổi, ngừng tuần hoàn ngoài cơ thể, trung hòa protamine; Kết thúc ca mổ. Thời gian tuần hoàn ngoài cơ thể 30 phút, không ngừng tim trong quá trình mổ.

Sau mổ, bệnh nhân được chuyển về phòng hồi sức tim mạch với huyết động ổn định, vận mạch dobutamin liều thấp, trao đổi phổi còn hạn chế. Siêu âm bụng ngay sau mổ: ổ tụ máu gan không tăng, dịch ổ bụng không tăng. X-quang phổi: hình ảnh phù kẽ phổi hai bên. Bệnh nhân được chỉ định băng chun hai chân và cho heprin từ ngày thứ 2 sau mổ. Diễn biến sau đó thuận lợi và bệnh nhân được rút nội khí quản vào ngày thứ 3 sau mổ. Sau đó 10 ngày được tiến hành mổ kết hợp xương cẳng chân phải và xuất viện sau 15 ngày.

Trên MSCT ngực trước ra viện, các nhánh động mạch phổi không có huyết khối, phổi hai bên nở tốt. Siêu âm Doppler tim thấy chức năng tim phải bình thường, áp lực động mạch phổi không cao, van ba lá hở nhẹ.
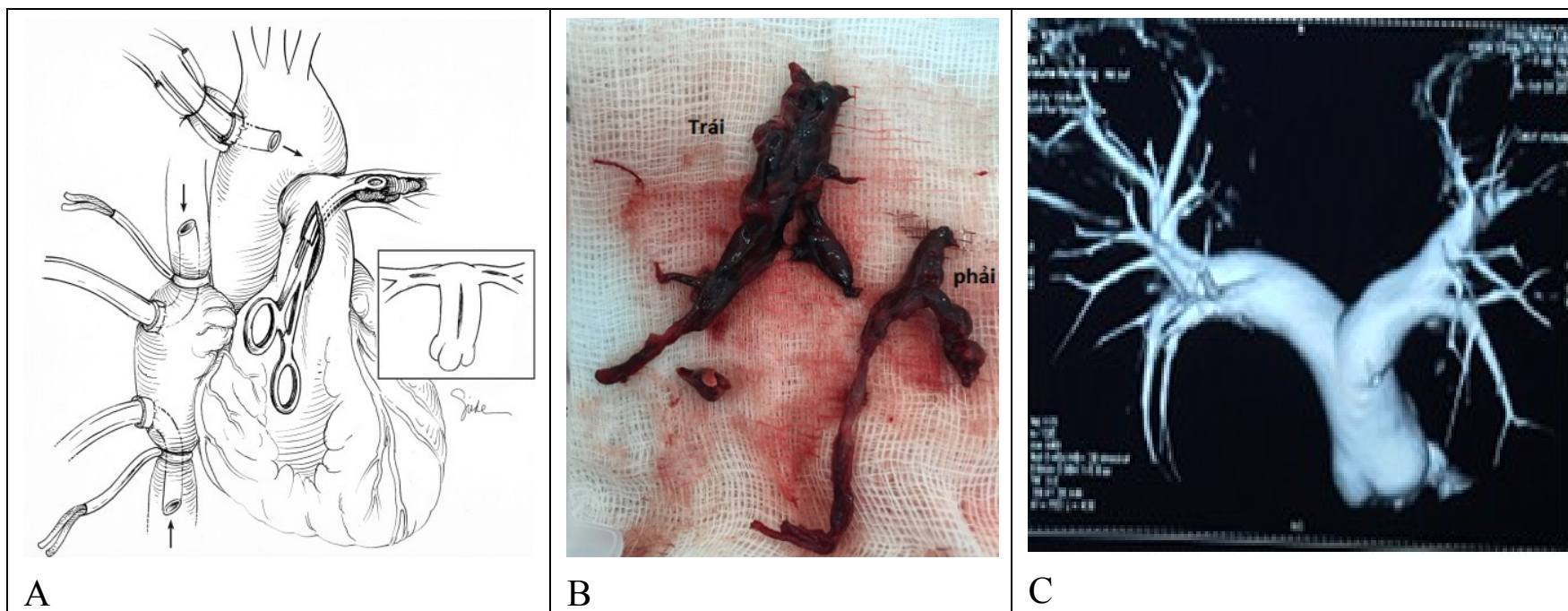

B

C

Anh 2: 2A-So đồ phẫu thuật[2], 2B-Hình ảnh huyết khối tù ĐMP, 2C-Hình ảnh MSCT động mạch phổi sau mổ.

\section{BÀN LUẬN}

4.1. Co chế bệnh sinh của TTĐMP: cơ chế bệnh TTĐMP được Virchow miêu tả vào cuối thế kỷ 19; và Friedrich Trendelenburg bác sỹ người Đức, là người đi tiên phong trong việc phẫu thuật lấy huyết khối ĐMP.
Tuy nhiên tới năm 1924, học trò của ông, bác sỹ Martin Kirschner, mới thông báo ca phẫu thuật lấy huyết khối ĐMP thành công đầu tiên [4]. Các yếu tố nguy cơ dẫn đến hình thành huyết khối tĩnh mạch sâu - nguyên nhân trực tiếp của TTĐMP được trình bày ở bảng 1. [5] 
Bảng 1: Các yếu tố nguy co hình thành huyết khối tĩnh mạch sâu.

\begin{tabular}{|l|l|}
\hline Các yếu tố nguy cơ cao & $\begin{array}{l}\text { Gãy xương (đùi hoặc cẳng chân). } \\
\text { Thay khớp háng hay gối. } \\
\text { Các phẫu thuật lớn. } \\
\text { Chấn thương nặng. } \\
\text { Chấn thương tủy sống. }\end{array}$ \\
\hline Chẫu thuật nội soi khớp gối. \\
Óng đặt tĩnh mạch trung tâm. \\
Hóa trị. \\
Suy tim hoặc suy hô hấp mãn. \\
Điều trị hóc môn thay thế. \\
Ung thư di căn. \\
Dùng thuốc tránh thai. \\
Có thai, sau sinh. \\
Bại liệt. \\
Có tiền sử thuyên tắc mạch do huyết khối. \\
Bệnh tăng đông máu (trombophilia).
\end{tabular}

TTĐMP có ảnh hưởng đến huyết động và có biểu hiện lâm sàng khi gây tắc trên $30 \%$ $50 \%$ động mạch phổi [6]. Khi có TTĐMP làm tăng sức cản của ĐMP, gây giãn và suy thất phải. Cơ chế của đột tử chủ yếu của TTĐMP là do điện cơ phân ly. Trong trường hợp nhẹ hơn, thường bệnh nhân có triệu chứng ngất, hạ huyết áp, sốc. Với những bệnh nhân sống sót sau cơn TTĐMP cấp, hệ thần kinh giao cảm được hoạt hóa, các cơ chế nội sinh và ngoại sinh được kích thích, cơ chế Frank-Starling hoạt động làm tăng áp lực ĐMP, tăng lượng máu qua phổi, cùng với cơ chế co thắt mạch giúp cơ thể có thể duy trì huyết áp ổn định.

Cơn mất ổn định huyết động thứ hai thường xẩy ra sau khi TTĐMP 24-48 giờ, do có tái TTĐMP và /hoặc suy thất phải. Hầu hết do không phát hiện ra hoặc điều trị không hiệu quả TTĐMP. Suy thất phải có thể xẩy ra mà không có tái TTĐMP do cơ chế tự điều hòa không thể duy trì trong thời gian dài. Cơ thất phải cần lượng oxy lớn hơn, sự tưới máu thất phải giảm 
do huyết áp hệ thống giảm, sau TTĐMP phần phổi còn lại không thể đảm bảo oxy cho cơ thể, bão hòa oxy máu giảm, tất cả các yếu tố này dẫn đến suy thất phải. Ngoài ra giảm bão hòa máu, hạ huyết áp gây nên hội chứng cung lượng tim thấp, tăng áp lực động mạch phổi, tăng áp lực nhĩ phải gây dòng máu từ nhĩ phải sang nhĩ trái qua lổ bầu dục, tăng sự giảm bão hòa máu, tăng nguy cơ thuyên tắc đối nghịch và sốc. TTĐMP ít và ở ngoại vi không gây rối loạn huyết động, thường biểu hiện của nhồi máu phổi về lâm sàng và MSCT (đau tức ngực nhẹ, sốt nhẹ, đám mờ nhỏ trên X quang và MSCT ngực).

Đối chiếu với bệnh nhân trong nghiên cứu, thì lúc biểu hiện cấp tính trên lâm sàng là tương đương giai đoạn mất ổn định huyết động thứ hai do tái TTĐMP và suy giảm các cơ chế bù trừ.

4.2. Chẩn đoán TTĐMP: Khoảng $90 \%$ bệnh nhân TTĐMP có khó thở, đau ngực và ngất. Trong một số nghiên cứu, khó thở và đau ngực gặp ở hơn $90 \%$ bệnh nhân, cơn ngất ít gặp hơn nhưng là dấu hiệu của TTĐMP nặng, ngoài ra bệnh nhân còn có biểu hiện của sốc, hạ huyết áp và các dấu hiệu của huyết khối tĩnh mạch sâu. Trong các phương pháp cận lâm sàng cơ bản, thì $\mathrm{X}$-quang ngực thẳng là phương pháp thường dùng nhất - thấy có bất thường như xẹp phân thùy, thùy phổi, vòm hoành cao, tuy nhiên các dấu hiệu này không đặc hiệu của TTĐMP. Bão hòa oxy thường giảm $20 \%$ so với người bình thường. Trên điện tâm đồ có nhịp nhanh, và các dấu hiệu suy thất phải như sóng $\mathrm{T}$ âm ở các đạo trình $\mathrm{V} 1-\mathrm{V} 4$, bloc nhánh phải hoàn toàn hoặc không hoàn toàn. Tuy nhiên các dấu hiệu lâm sàng và cận lâm sàng cơ bản không cho phép khẳng định hay loại trừ TTĐMP.

Để có chẩn đoán bước đầu người ta đã đưa ra các thang điểm tính chỉ số nguy cơ TTĐMP dựa trên các nguy cơ gây huyết khối tĩnh mạch sâu chi dưới và phân ra bệnh nhân có nguy cơ thấp, vừa và cao, phổ biến nhất là bảng nguy cơ của Wells và Geneva (bảng 2) [5].

Bảng 2: Thang điểm nguy cơ TTĐMP

\begin{tabular}{|c|c|c|c|}
\hline \multicolumn{2}{|l|}{ Thang điểm Geneva } & \multicolumn{2}{|l|}{ Thang điểm Wells } \\
\hline Các tiêu chí & Điểm & Các tiêu chí & Điểm \\
\hline $\begin{array}{l}\text { Các yếu tố nguy cơ } \\
\text { Tuổi > } 65 \\
\text { Có tiền sử HKTMS hoặc } \\
\text { TTĐMP } \\
\text { Phẫu thuật hoặc gãy xương } \\
\text { trong vòng } 1 \text { tháng. } \\
\text { Ung thư di căn }\end{array}$ & $\begin{array}{l}+1 \\
+3 \\
+2 \\
+2\end{array}$ & $\begin{array}{l}\text { Các yếu tố nguy cơ } \\
\text { Có tiền sử HKTMS hoặc TTĐMP } \\
\text { Mới phẫu thuật hoặc bất động } \\
\text { Ung thư }\end{array}$ & $\begin{array}{c}+1.5 \\
+1.5 \\
+1\end{array}$ \\
\hline $\begin{array}{l}\text { Triệu chứng } \\
\text { Đau chân } 1 \text { bên } \\
\text { Ho ra máu }\end{array}$ & $\begin{array}{l}+3 \\
+2\end{array}$ & $\begin{array}{l}\text { Triệu chứng } \\
\text { Ho ra máu }\end{array}$ & +1 \\
\hline
\end{tabular}




\begin{tabular}{|c|c|c|c|}
\hline $\begin{array}{l}\text { Các dấu hiệu lâm sàng } \\
\text { Nhịp tim: } 75-94 \text { lần/phút } \\
\qquad \geq 95 \text { lần/phút } \\
\text { Đau khi thăm khám tĩnh mạch } \\
\text { sâu chi dưới hoặc phù } 1 \text { chân }\end{array}$ & $\begin{array}{l}+3 \\
+5 \\
+4\end{array}$ & $\begin{array}{l}\text { Các dấu hiệu lâm sàng } \\
\text { Nhịp tim: > } 100 \text { lần/ phút } \\
\text { Dấu hiệu của HKTMS } \\
\text { Chẩn đoán khác ít khả năng hơn } \\
\text { TTĐMP }\end{array}$ & $\begin{array}{l}+3 \\
+3\end{array}$ \\
\hline Khả năng TTĐMP & Tổng & Khả năng TTĐMP & Tổng \\
\hline $\begin{array}{l}\text { Thấp } \\
\text { Vừa } \\
\text { Cao }\end{array}$ & $\begin{array}{l}0-3 \\
4-10 \\
\geq 11\end{array}$ & $\begin{array}{l}\text { Thấp } \\
\text { Vừa } \\
\text { Cao }\end{array}$ & $\begin{array}{l}0-1 \\
2-6 \\
\geq 7\end{array}$ \\
\hline & & $\begin{array}{l}\text { Thang điểm hai bậc } \\
\text { Ít nguy cơ TTĐMP } \\
\text { Nhiều nguy cơ TTĐMP }\end{array}$ & $\begin{array}{c}0-4 \\
>4\end{array}$ \\
\hline
\end{tabular}

Các phương pháp cận lâm sàng chẩn đoán huyết khối tĩnh mạch sâu (HKTMS): Ddimer là sản phẩm của quá trình phân hủy fibrin, nếu thử $\mathrm{D}$-dimer âm tính có thể loại trừ TTĐMP ở bệnh nhân có thang điểm nguy cơ TTĐMP thấp và vừa. Doppler mạch chi dưới hoặc chụp cắt lớp tĩnh mạch có cản quang dựng hình cho phép loại trừ HKTMS chi dưới.

Xạ hình phổi: là phương pháp cho phép đánh giá tưới máu phổi có dùng chất phóng xạ technetium (Tc)-99 m. Nếu kết quả xạ hình phổi bình thường thì có thể loại trừ TTĐMP. Tuy nhiên kỹ thuật khá phức tạp, khó ứng dụng trong cấp cứu.

Chụp cắt lớp vi tính động mạch phổi (ĐMP), đặc biệt là chụp MSCT ngực và ĐMP, cho phép đánh giá chính xác có hay không huyết khối trong hệ ĐMP. Đây là phương pháp chẩn đoán ít xâm lấn có độ đặc hiệu cao thường được sử dụng.

Chụp động mạch phổi có cản quang: ngày nay ít sử dụng do đây là phương pháp chẩn đoán xâm lấn, chỉ sử dụng khi các phương pháp khác không loại trừ được TTÐMP.

Siêu âm Doppler tim: cho phép đánh giá các dấu hiệu gián tiếp của TTĐMP như hở van ba lá, suy thất phải (giãn thất phải, giảm vận động thành thất phải, tăng tỉ lệ đường kính thất phải/ thất trái).

Bệnh nhân nghiên cứu có bệnh cảnh điển hình của TTĐMP cấp với các yếu tố nguy cơ như: sau đa chấn thương, có chấn thương chi, nằm bất động, khó thở, đau ngực. Các thăm khám sâu hơn cận lâm sàng như xét nghiệm Ddimer, siêu âm tĩnh mạch chi dưới, siêu âm tim và đặc biêt là chụp MSCT động mạch phổi cho phép chẩn đoán chính xác TTĐMP ở bệnh nhân này.

4.3. Điều trị TTĐMP: Kết quả điều trị TTĐMP phụ thuộc nhiều vào bệnh cảnh lâm sàng của bệnh nhân. Để có phác đồ điều trị thích hợp, Hiệp hội tim mạch Hoa Kỳ phân TTĐMP thành ba nhóm: TTĐMP nhiều, vừa và ít, đặc điểm của các nhóm được trình bày ở bảng 3 [7]. 


\section{Bảng 3: Phân loại TTĐMP theo Hiệp hội tim mạch Hoa Kỳ}

\begin{tabular}{|l|l|}
\hline TTĐMP nhiều & $\begin{array}{l}\text { TTĐMP cấp có hạ huyết áp (huyết áp tâm trương } \leq 90 \mathrm{~mm} \mathrm{Hg} \text { trong ít nhất } \\
15 \text { phút hoặc cần thuốc vận mạch hỗ trợ mà không do lý do khác), nhịp nhanh } \\
\text { hoặc chậm hơn } 40 \text { lần phút với dấu hiệu sốc. }\end{array}$ \\
\hline TTĐMP vừa & $\begin{array}{l}\text { TTĐMP cấp không có hạ huyết áp (huyết áp tâm trương } \geq 90 \mathrm{~mm} \mathrm{Hg} \text { ) với } \\
\text { dấu hiệu suy tim phải hoặc nhồi máu cơ tim. }\end{array}$ \\
\hline TTĐMP ít & $\begin{array}{l}\text { TTĐMP cấp có huyết áp bình thường, không có dấu hiệu suy tim phải hoặc } \\
\text { nhồi máu cơ tim. }\end{array}$ \\
\hline
\end{tabular}

Điều trị TTĐMP phải kết hợp nhiều phương pháp. Ngay sau khi có chẩn đoán TTĐMP, bệnh nhân cần được chỉ định dùng thuốc chống đông ngay, thường là heparin hoặc heparin trọng lượng phân tử thấp (Lovenox). Bước tiếp theo cần xác định phương pháp xử lý huyết khối ĐMP. Theo các khuyến cáo hiện nay nếu không có chống chỉ định, đối với TTĐMP nhiều và vừa phương pháp lựa chọn đầu tiên là dùng thuốc tiêu sợi huyết (streptokinase, urokinase) [3],[5],[7], các kết quả nghiên cứu cho thấy thuốc tiêu sợi huyết cho kết quả tốt như hạ áp lực ĐMP, tăng bão hòa oxy [8],[9],[10].

Trong trường hợp có chống chỉ định dùng thuốc tiêu sợi huyết và không thể tiến hành phẫu thuật lấy huyết khối, có thể can thiệp qua da điều trị TTĐMP với ba phương pháp chính bao gồm: hút huyết khối, đánh nhỏ huyết khối, đánh nhỏ và hút huyết khối. Kết quả điều trị theo phương pháp này cũng khá khả quan, tuy nhiên cần các dụng cụ chuyên dụng và tốn kém [9].

Phẫu thuật lấy huyết khối có sử dụng tuần hoàn ngoài cơ thể là phương pháp được lựa chọn khi có chống chỉ định với thuốc tiêu sợi huyết, đặc biệt đối với bệnh nhân có huyết khối nhĩ phải hoặc thuyên tắc đối nghịch. Những nghiên cứu trước đây cho tỉ lệ tử vong từ 20-30\% sau mổ lấy huyết khối ĐMP [11], tuy nhiên cùng với sự tiến bộ của phẫu thuật tim mạch ngày nay tỉ lệ này giảm đáng kể (4\%) [12].

Trên bệnh nhân nghiên cứu, các triệu chứng bệnh tương ứng với loại TTĐMP nhiều, bệnh nhân có chống chỉ định dùng thuốc tiêu sợi huyết do chấn thương gan, vì vậy có chỉ định phẫu thuật lấy huyết khối với tuần hoàn ngoài cơ thể. Nghiên cứu y văn, chúng tôi thấy có nhiều kỹ thuật lấy huyết khối ĐMP, tuy nhiên các thông báo mới nhất thiên về kỹ thuật không ngừng tim [1], đây là kỹ thuật có tỉ lệ biến chứng và tử vong thấp, và chúng tôi đã áp dụng phương pháp này. Bệnh nhân này có chấn thương gan nên vấn đề dùng heparin liều cao trong phẫu thuật được cân nhắc, chúng tôi dung liều $200 \mathrm{UI} / \mathrm{kg}$ sau đó thử $\mathrm{ACT}$ và tiếp tục dò liều, thay vì dùng liều 300UI/kg như mổ tim hở thường quy. Sau phẫu thuật việc xét đặt lọc tĩnh mạch chủ dưới (inferior cava filter) cũng được cân nhắc, kết quả siêu âm mạch cho thấy chỉ có huyết khối ở tĩnh mạch khoeo trở xuống và tình trạng chấn thương gan ổn định, không chảy máu tăng, sau mổ bệnh nhân dùng heparin trọng lượng phân tử thấp và sau đó là thuốc kháng Xa (xarento), đeo tất chun như điều trị HKTMS nên không có chỉ định đặt lọc tĩnh mạch chủ dưới.

\section{KẾT LUẬN}

TTĐMP là bệnh khó chẩn đoán trong bệnh cảnh đa chấn thương, có tỉ lệ tử vong cao, đối 
với trường hợp TTĐMP nhiều và vừa thì phẫu thuật lấy huyết khối ĐMP có tuần hoàn ngoài cơ thể không ngừng tim là phương pháp an toàn, cho kết quả tốt.

\section{TÀI LIỆU THAM KHẢO}

1. Nguyễn Hữu Ước, Phùng Duy Hồng Son, Nguyễn Ngọc Thọ,(2017) Phẫu thuật điều trị thuyên tắc động mạch phồi cấp tính kết quả lâu dài từ 2 ca phẫu thuật tại Bệnh viện Việt Đức, Y học thực hành (1049), số 6/2017, trang 131-135.

2. Hui D.S, Mcfadden P.M, (2013) Contemporary Surgical Management of Acute Massive Pulmonary Embolism, in Principles and Practice of Cardiothoracic Surgery, M. Firstenberg, pp. 395-412.

3. Konstantinides S. Kasper W, Et Al. (1997), "Management strategies and determinants of outcome in acute major pulmonary embolism: results of a multicenter registry", J Am Coll Cardiology, 30(5), pp. 1165-1171.

4. Ochsner J.L, Mcfadden P.M, (2002), "A history of the diagnosis and treatment of venous thrombosis and pulmonary embolism", Ochsner J, 4(1), pp. 9-13.

5. Perrier A, Chairperson A.T, Et Al (2008), "Guidelines on the diagnosis and management of acute pulmonary embolism. The Task Force for the Diagnosis and Management of Acute Pulmonary Embolism of the European Society of Cardiology", European Heart Journal, 29, pp. 2276-2315.

6. Sasahara A, Mcintyre K, (1971), "The hemodynamic response to pulmonary embolism in patients without prior cardiopulmonary disease. ", Am J Cardiol 28(3), pp. 288-294.

7. Mcmurtry M.S, Jaft R.M, Et Al, (2011), "Management of Massive and Submassive Pulmonary Embolism,Iliofemoral Deep Vein Thrombosis, and Chronic Thromboembolic Pulmonary Hypertension: A Scientific Statement From the American Heart Association", Circulation, 123, pp.1788-1830.

8. Pioped Investigators (1990), "Tissue plasminogen activator for the treatment of acute pulmonary embolism: a collaborative study by the PIOPED Investigators", Chest, 97(3), pp. 528-533.

9. Hirsh J, Levine M, Et Al, (1990), " $A$ randomized trial of a single bolus dosage regimen of recombinant tissue plasminogen activator in patients with acute pulmonary embolism", Chest, 98(6), pp. 1473-1479.

10. Tiede N, Konstantinides S, Et Al, (1998), "Comparison of alteplase versus heparin for resolution of major pulmonary embolism", Am J Cardiol, 82(8), pp. 966-970.

11. Tiede N, Konstantinides S, Et Al, (2007), "Outcome of pulmonary embolectomy", Am J Cardiol, 99, pp. 421-423.

12. Unic D, Leacche M, Et Al, (2005), "Modern surgical treatment of massive pulmonary embolism: results in 47 consecutive patients after rapid diagnosis and aggressive surgical approach", J Thorac Cardiovasc Surg, 129(5), pp. 1018-1023. 